\title{
Form Distribution Characteristics of Nitrogen in a Reservoir as Drinking Water Source
}

\author{
Lahua Jin, Chen Zhao, Jiayi Wang \\ School of Environment, Jinan University, Guangzhou, China \\ Email: profjin@163.com
}

How to cite this paper: Jin, L.H., Zhao, C. and Wang, J.Y. (2016) Form Distribution Characteristics of Nitrogen in a Reservoir as Drinking Water Source. Journal of Environmental Protection, 7, 2018-2024. http://dx.doi.org/10.4236/jep.2016.713156

Received: October 25, 2016

Accepted: December 13, 2016

Published: December 16, 2016

Copyright $\odot 2016$ by authors and Scientific Research Publishing Inc. This work is licensed under the Creative Commons Attribution International License (CC BY 4.0).

http://creativecommons.org/licenses/by/4.0/

\begin{abstract}
Based on field detected water quality data, the distribution characteristics of different forms of nitrogen in a reservoir as drinking water source in Dongguan, which locates at the Pearl River Delta of China, have been analyzed in order to provide theoretical bases for prevention and reduction of eutrophication. The analyzed results show that nitrogen forms in the influent area of the reservoir are given priority to ammonia nitrogen and nitrate nitrogen, whose proportion is more than $45 \%$ respectively, and this is probably caused by the pollution of inflow water quality; but in the effluent area, the forms are given priority to nitrate nitrogen, whose proportion is as high as $96 \%$ and above; also the proportion of ammonia nitrogen drops by more than $80 \%$ during the process from the influent area to the effluent area, and this shows that the natural process of nitrification and denitrification can be well accomplished in the reservoir. We recommend here that to reduce the input amount of ammonia nitrogen and organic nitrogen into the reservoir is the most efficient way to prevent or mitigate eutrophication of water body.
\end{abstract}

\section{Keywords}

Nitrogen Form, Reservoir for Drinking Water Source, Eutrophication, Dissolved Organic Nitrogen

\section{Introduction}

Nitrogen pollution in a reservoir not only can promote the degree of water body eutrophication, but also will generate disinfection by-products of nitrogen (N-DBPs) during the process of chlorine disinfection when the water is pumped to prepare for dinking. The N-DBPs are carcinogenic and most harmful to human health. In order to control this risk, it is necessary to make clear distribution regulation of nitrogen forms and their variation in a reservoir. 
But up-to-date, researches on nitrogen form characteristics in a reservoir are still few. Xiaoli Ge et al. investigated geochemical characteristics of water body in Reservoir Miyun in Beijing during 2001, and found out that TN/TP ratio was as high as 38.4:1 and pointed out that phosphorus is the major nutrient element limiting biological productivity [1]. Yeqing Feng et al. investigated the mean concentrations of TN, TP, chlorophyll-a and SD in Reservoir Hongfeng located on the Guizhou plateau in southwest China in 2010 as $1.83 \mathrm{mg} / \mathrm{L}, 0.034 \mathrm{mg} / \mathrm{L}, 0.0127 \mathrm{mg} / \mathrm{L}$ and $2.3 \mathrm{~m}$ respectively, which shows that the water body in the reservoir was in meso-eutrophic state [2]. Yuejuan Lin analyzed and assessed the characteristics of sediment cores and their overlaying water quality. The results show that concentration of total nitrogen is relatively low in both summer and winter but much high in both spring and autumn [3]. Yunxian Dong et al. established 9 sampling plots on 3 sections in Lake Chenghai located in Yunnan of China by global positioning system to study the speciation and distribution of nitrogen and phosphorus, and their relationships with chlorophyll-a, and the results indicated that the total nitrogen, total phosphorus and total chlorophyll-a in the lake water were $0.773 \mathrm{mg} / \mathrm{L}, 0.046$ $\mathrm{mg} / \mathrm{L}$ and $0.024 \mathrm{mg} / \mathrm{L}$ respectively, and the majority of the total nitrogen was dissolved nitrogen in which dissolved organic nitrogen was predominant, while dissolved inorganic phosphorus consisted of majority of the total phosphorus [4]. Fengjiao Wang analyzed the geochemical behavior of nitrogen, phosphorus and other biogenic elements in the overlaying water and sediment of the Hulun Lake in arid areas within the Mongolian Plateau, and found out that the main existing form of nitrogen is the organic nitrogen in the lake [5]. Honelei Yu (2013) analyzed the distribution and transformation of DON in both landscape water and effluent water from different treatment processes in municipal sewage treatment plants, and concluded that there was seasonal variation in the concentrations of DON in the landscape water, and there was significant difference between the north and south part in different months. And DON in landscape water is the potential nutrition of algae, and it is remarkable in the process of eutrophication control [6]. So far, the distribution and its variation of nitrogen forms in a reservoir as drinking water source are still not clear and need to be further deeply studied. Thus, we have taken Reservoir TS, which locates at Dongguan of Guangdong Province in China, as an example to analyze the distribution characteristics and its spatial and temporal variation of nitrogen forms in reservoir.

\section{Survey of the Reservoir}

\subsection{Basic Condition}

Reservoir TS is located in southeast of Dongguan city. It has catchment area of $100 \mathrm{~km}^{2}$ and total capacity of 65.2 million $\mathrm{m}^{3}$, as shown in Figure 1 . It was classified as one of the backup drinking water sources for the city in 2006. Huanyan Huang et al. indicated after analyzed the detected water quality data that the reservoir is in a state of slight pollution [7], and Jiao Han discussed the environmental capacity of the reservoir [8]. 


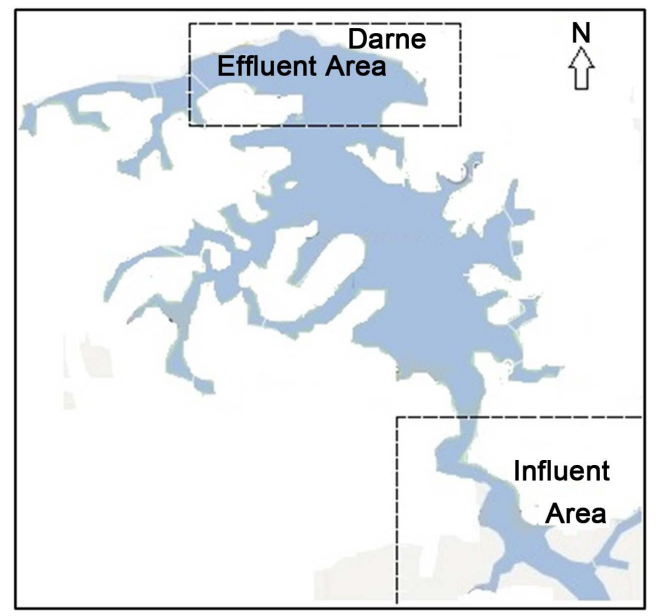

Figure 1. Plan of reservoir TS.

\subsection{Survey Result}

During the period from April 2014 to January 2016, we sampled water quality and nutritional level of the reservoir. According to the water quality requirement of China National Environmental Quality Standards for Surface Water (GB3838-2002), the single factor standard indexes of the water quality have been calculated out as shown in Table 1 based on the detected data. It can be seen from the table that there exist five indexes exceeded the national standard, i.e., $\mathrm{COD}_{\mathrm{Mn}}, \mathrm{COD}_{\mathrm{cr}}$, ammonia nitrogen, $\mathrm{BOD}_{5}$ and total phosphorus. Thus, it has been shown from this phenomenon that the reservoir has been obviously contaminated by organic and nutrient pollutants.

Based on the monitored data of water body nutritional level, the comprehensive nutritional status index of the reservoir has been calculated out as shown in Figure 2 according to the improved comprehensive nutrition state index calculation method provided by Rui Zhang et al. [9]. It has been shown from Figure 2 that the reservoir is at meso-eutrophic status, but its nutritional level has a decrease trend. But the degree of comprehensive nutrition in the effluent area is lower than that in the influent area of the reservoir. This shows that the reservoir has good self-purification ability because nutrient pollutants can be degraded obviously from influent area to effluent area.

\section{Nitrogen Form Distribution Characteristics}

Nitrogen in water can be mainly divided into inorganic nitrogen and organic nitrogen. Usually, inorganic nitrogen includes ammonia nitrogen and nitric nitrogen, in which the ammonia nitrogen includes free ammonia nitrogen $\left(\mathrm{NH}_{3}-\mathrm{N}\right)$ and ammonium nitrogen $\left(\mathrm{NH}_{4}^{+}-\mathrm{N}\right)$, and the nitric nitrogen includes nitrate nitrogen $\left(\mathrm{NO}_{3}-\mathrm{N}\right)$ and nitrite nitrogen $\left(\mathrm{NO}_{2}-\mathrm{N}\right)$. But organic nitrogen in water contains a lot of organic compounds, such as urea, amino acid, protein, nucleic acid, uric acid, fatty amine, organic base, amino sugar and so on. The concentration and proportion of different forms of nitrogen in water are often determined by specific circumstances of the water body. 


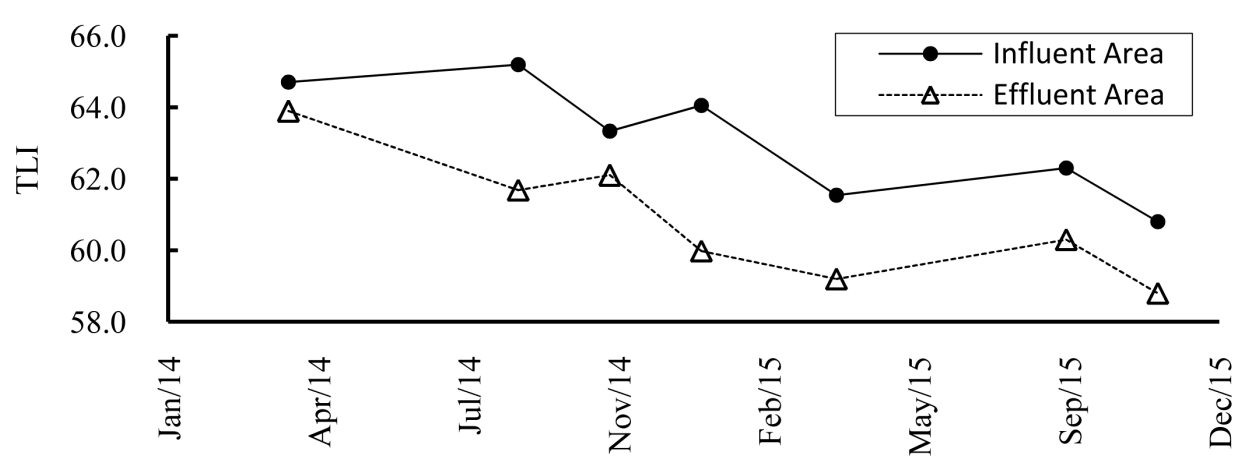

Figure 2. Variation of the comprehensive nutritional status index TLI of the reservoir.

Table 1. Present status of water quality standard indexes of the reservoir.

\begin{tabular}{|c|c|c|c|c|}
\hline \multirow{2}{*}{ Item } & \multicolumn{3}{|c|}{ Standard Index } & \multirow{2}{*}{ Status } \\
\hline & Influent area & Effluent area & Average & \\
\hline $\mathrm{pH}$ & 0.085 & 0.098 & 0.091 & Qualified \\
\hline DO & 0.273 & 0.204 & 0.239 & Qualified \\
\hline $\mathrm{COD}_{\mathrm{Mn}}$ & 1.080 & 0.963 & 1.022 & Exceed standard \\
\hline $\mathrm{COD}_{\text {cr }}$ & 1.020 & 1.370 & 1.195 & Exceed standard \\
\hline Ammonia nitrogen & 2.768 & 1.498 & 2.133 & Exceed standard \\
\hline $\mathrm{BOD}_{5}$ & 1.265 & 1.690 & 1.478 & Exceed standard \\
\hline $\mathrm{TP}$ & 2.960 & 2.240 & 2.600 & Exceed standard \\
\hline Petroleum class & 0.800 & 0.800 & 0.800 & Qualified \\
\hline Anionic surface-active agent & 0.150 & 0.150 & 0.150 & Qualified \\
\hline Volatile phenol & 0.100 & 0.100 & 0.100 & Qualified \\
\hline Sulfide & 0.015 & 0.015 & 0.015 & Qualified \\
\hline Cyanide & 0.003 & 0.003 & 0.003 & Qualified \\
\hline Zinc & 0.010 & 0.008 & 0.009 & Qualified \\
\hline Copper & 0.004 & 0.003 & 0.004 & Qualified \\
\hline Lead & 0.001 & 0.001 & 0.001 & Qualified \\
\hline Cadmium & 0.006 & 0.006 & 0.006 & Qualified \\
\hline Selenium & 0.010 & 0.010 & 0.010 & Qualified \\
\hline Mercury & 0.050 & 0.050 & 0.050 & Qualified \\
\hline Arsenic & 0.023 & 0.024 & 0.024 & Qualified \\
\hline Chromium of six valence & 0.040 & 0.040 & 0.040 & Qualified \\
\hline Fluoride & 0.672 & 0.538 & 0.605 & Qualified \\
\hline
\end{tabular}

\subsection{Proportion of Different Forms of Nitrogen}

The proportion of different forms of nitrogen in the reservoir has been analyzed base on the detected data of water quality, and the result shows that inorganic nitrogen oc- 
cupies most proportion of total nitrogen, and its proportion is as high as over $92 \%$ in the influent area or over $84 \%$ in the effluent area at any time, but the organic nitrogen only occupies below $8 \%$ in the influent area or below $16 \%$ in the effluent area at any time, as shown in Figure 3.

The inorganic nitrogen in the reservoir is found to be composed of ammonia nitrogen and nitric nitrogen, and their average proportions during the detecting period are $49.9 \%$ and $50.1 \%$ in the influent area, and $48.5 \%$ and $51.5 \%$ in the effluent area respectively, as shown in Table 2.

The nitric nitrogen in the reservoir is also found to be composed of about $96 \%-99 \%$ of nitrate nitrogen and $1 \%-4 \%$ of nitrite nitrogen, as shown in Table 3.

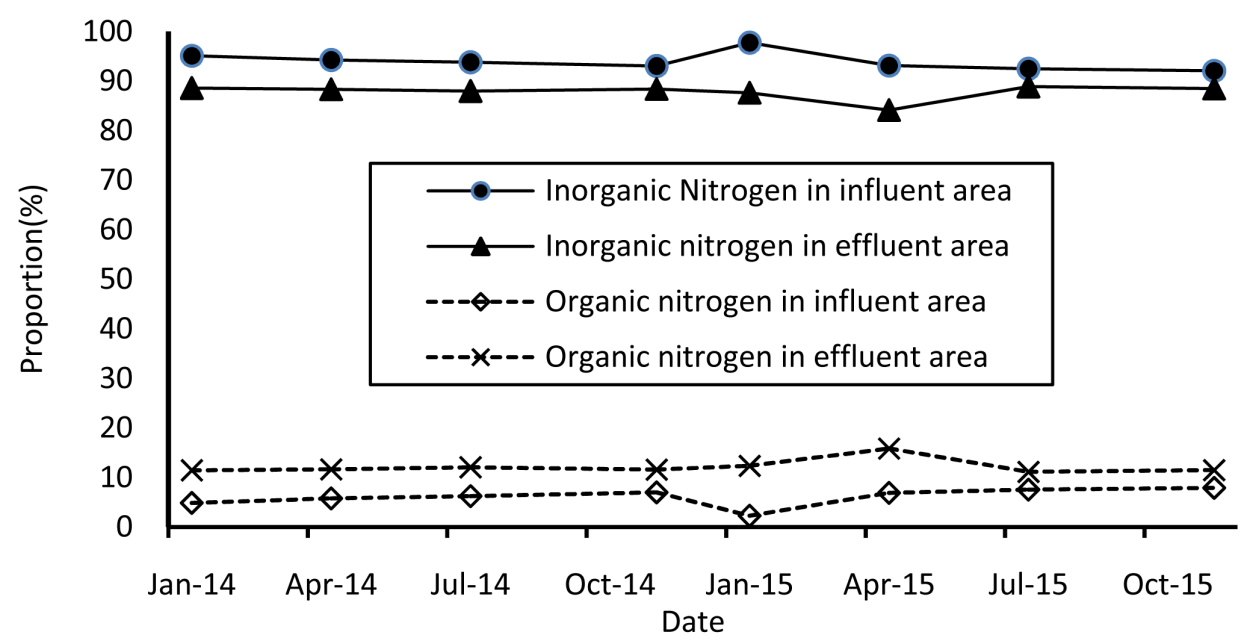

Figure 3. Variation of proportion of inorganic and organic nitrogen in the reservoir.

Table 2. Composition proportion of inorganic nitrogen in the reservoir.

\begin{tabular}{cccccccccccc}
\hline \multirow{2}{*}{ Nitrogen form } & \multicolumn{8}{c}{ Proportion (\%) } \\
\cline { 3 - 10 } & & Jan-14 & Apr-14 & July-14 & Nov-14 & Jan-15 & Apr-15 & July-15 & Nov-15 & Average \\
\hline \multirow{2}{*}{$\begin{array}{c}\text { Ammonia } \\
\text { Nitrogen }\end{array}$} & Influent & 52 & 51 & 51 & 51 & 49 & 48 & 48 & 49 & 49.9 \\
& Effluent & 51 & 50 & 49 & 49 & 48 & 47 & 47 & 47 & 48.5 \\
Nitric & Influent & 48 & 49 & 49 & 49 & 51 & 52 & 52 & 51 & 50.1 \\
Nitrogen & Effluent & 49 & 50 & 51 & 51 & 52 & 53 & 53 & 53 & 51.5 \\
\hline
\end{tabular}

Table 3. Composition proportion of nitric nitrogen in the reservoir.

\begin{tabular}{cccccccccccc}
\hline \multirow{2}{*}{ Nitrogen form } & \multicolumn{8}{c}{ Proportion (\%) } \\
\cline { 3 - 10 } & & Jan-14 & Apr-14 & July-14 & Nov-14 & Jan-15 & Apr-15 & July-15 & Nov-15 & Average \\
\hline \multirow{2}{*}{ Nitrate } & Influent & 98 & 98 & 98 & 98 & 97 & 96 & 96 & 96 & 97.1 \\
Nitrogen & Effluent & 99 & 99 & 99 & 98 & 97 & 96 & 96 & 96 & 97.5 \\
\cline { 3 - 10 } Nitrite & Influent & 2 & 2 & 2 & 2 & 3 & 4 & 4 & 4 & 2.9 \\
Nitrogen & Effluent & 1 & 1 & 1 & 2 & 3 & 4 & 4 & 4 & 2.5 \\
\hline
\end{tabular}


It can be concluded from the above analyses that the proportion of different forms of nitrogen in the reservoir are $45.0 \%$ of nitrate nitrogen, $44.7 \%$ of ammonia nitrogen, $9.1 \%$ of organic nitrogen and $1.2 \%$ of nitrite nitrogen.

\subsection{Spatial Distribution of Different Forms of Nitrogen}

The spatial distribution of inorganic nitrogen and organic nitrogen has obvious differences in the reservoir, i.e., during the process from the influent area to the effluent area, the inorganic nitrogen will degrade about $6.1 \%$, but the organic nitrogen will increase about 6.1\%, as shown in Figure 3.

The degradation of inorganic nitrogen may be caused by the reaction of its nitrification and denitrification. This phenomenon demonstrates that the water quality is getting improved and the self-purification ability of water is strong in the reservoir.

\section{Conclusions}

Nitrogen forms in a reservoir as drinking water source behave as over $84 \%$ of inorganic nitrogen and below $16 \%$ of organic nitrogen. The inorganic nitrogen is composed of ammonia nitrogen and nitric nitrogen, in which the nitric nitrogen is mostly composed by nitrate nitrogen.

The proportion of inorganic nitrogen in the influent area is some higher than those in the effluent area, but the proportion of organic nitrogen is little lower in the influent area than those in the effluent area.

Reservoirs as drinking water source may have essential capability of self-purification to degrade nutrient pollution.

\section{Acknowledgements}

This work has been supported by Guangdong provincial scientific technology project fund (No. 2015A020215015).

\section{References}

[1] Ge, X.L., Liu, X.D., Pan, X.C., Li, Q. and Luo, S.-G. (2003) The Geochemical Characteristics of Water Bodyin Miyun Reservoir. Rock and Mineral Analysis, 22, 44-48.

[2] Feng, Y.Q., Xia, P.H., Zhang, M.S., Li, C.X., Lin, T., Ma, J.R., Long, J. and Yang, J.J. (2011) Analysis on Eutrophication Features of Hongfeng Reservoir on Guizhou Plateau. Journal of Guizhou Normal University (Natural Sciences), 29, 29-35.

[3] Lin, Y.J. (2005) Distribution of Nitrogen and Phosphorus in Sediment Core and Overlay Water of Donghu Lake. Master's Degree Thesis, Wuhan University, Wuhan.

[4] Dong, Y.X., Hong, X.H., Tan, Z.W., Zhu, X. and Li, Y.Q. (2012) Distribution of Nitrogen and Phosphorus and Their Relationships with Chlorophylla in Lake Chenghai on Plateau. Journal of Ecology and Environmental Sciences, 21, 333-337.

[5] Wang, F.J. (2010) Geochemistry Characteristics of Nitrogen and Phosphorus of the Hulun Lake. Master's Degree Thesis, Inner Mongolia University, Huhhot.

[6] Yu, H.L. (2013) Study on the Characteristics of Dissolved Organic Nitrogen in Wastewater and Landscape Water. Master's Degree Thesis, Anhui Normal University, Wuhu. 
[7] Huang, H.Y., Zeng, R., Li, X.W., Xia, H.Z. and Liu, H.R. (2007) Fuzzy Mathematics Comprehensive Evaluation of Water Environment Quality of Reservoir Tongsha. Chinese Journal of Industrial Water Usage \& Wastewater, 42, 42-44.

[8] Han, J. (2013) Analysis on Water Environmental Capacity of the Tongsha Reservoir. Chinese Journal of Henan Science and Technology, No. 4, 180-181.

[9] Zhang, R., Gao, L.M., Xi, B.D., Su, J., Huo, S.L., et al. (2014) Improved TLI Index Method and Its Application in Nutritional States Evaluation in Chaohu Lake. Chinese Journal of Environmental Engineering, 7, 2127-2132.

Submit or recommend next manuscript to SCIRP and we will provide best service for you:

Accepting pre-submission inquiries through Email, Facebook, LinkedIn, Twitter, etc. A wide selection of journals (inclusive of 9 subjects, more than 200 journals)

Providing 24-hour high-quality service

User-friendly online submission system

Fair and swift peer-review system

Efficient typesetting and proofreading procedure

Display of the result of downloads and visits, as well as the number of cited articles

Maximum dissemination of your research work

Submit your manuscript at: http://papersubmission.scirp.org/

Or contact jep@scirp.org 